J. Perinat. Med. 8 (1980) 195

\title{
Normalization of blood glucose in pregnant diabetics with the maximal tolerated dose (M.T.D.) of insulin**
}

\author{
G. D. Roversi, M. Gargiulo*, U. Nicolini*, E. Pedretti*, E. Ferrazzi*, L. Gruft* \\ * 1 st Department of Obstetrics and Gynaecology, University of Milan, Italy
}

\section{Introduction}

The perinatal results achieved through compensating maternal diabetes by administering the M.T.D. of insulin are positive. They have already been reported $[1,5,6,7,8,10]$ and consist of: 1) a reduction in perinatal mortality (P.M.) to values (total P.M. 2.9\%, corrected P.M. 1.9\%) of the general P.M. (in 1975 total P.M. of the general population in the Clinic $2.5 \%$ ); 2) near disappearance of foetal macrosomia (3.3\% above $4000 \mathrm{~g}$ ) and normalization of birth weight (newborn weight does not differ from normal newborn weight) [9]; 3) a normal incidence of pathological symptoms in newborn infants which were not however severe (respiratory distress syndrome $0.6 \%$, hypoglycemia $13.4 \%$ ); 4) reduction of caesarian sections to $24.6 \%$; 5) delivery time did not have to be systematically brought forward, but only in cases where poor conditions of the foetus were apparent (labour induced in $9.6 \%$ of cases): $74.7 \%$ of the cases gave birth after the 38th week of gestation.

The M.T.D. of insulin is the highest quantity of insulin that can be administered without bringing about hypoglycemia. M.T.D. is easily established in a few days by increasing insulin dosage every day with a "small quantity" of fast-acting insulin and then subtracting the last, "small quantity" after the appearance of the first signs of insulin intolerance $[4,5,6,7,8,10]$. The maternal dia- betes results compensated to a degree that can be defined "as strict as possible". According to this method of treatment, maternal glycemia was not used in our case study as a guideline to insulin therapy. However, starting in 1971, the 24 hour blood sugar level was routinely checked in order to quantify the above qualitative definition of the degree of compensation. Preliminary data showed that maternal blood glucose levels out into a normal range when the insulin M.T.D. has been reached [10]. This paper provides a more detailed study of this aspect.

\section{Materials and methods}

Starting in 1971 hospitalized pregnant diabetics underwent a 24-hour glycemia check on a fixed day (Wednesday) of every week. It consisted of 6 samples of capillary blood collected every 4 hours, i.e. at 8 a.m., 12 a.m., 4 p.m., 8 p.m., 12 p.m. and 4 a.m. The patients had fasted from midnight until the 8 a.m. meal. Meals, as usual, were served at 8 a.m., 12 a.m., 4 p.m. and 6.30 p. $\mathrm{m}$. The $12 \mathrm{a} . \mathrm{m}$. and 6.30 p.m. meals were the two main meals of the day. In view of the time relationship between meals and blood sampling (Fig. 1), 5 out of the 6 samples represent the lower blood glucose levels over the 24 hours (the three samples at 8 a.m., 12 a.m. and 4 p.m. were taken 4 hours after the last meal and immediately before

\footnotetext{
** These results were presented at the IXth Meeting of the "Diabetic Pregnancy Study Group", Dubrovnik (Yugoslavia), 30th Sept.-4th Oct. 1978
} 
the following one; the two samples at 12 p.m. and 4 a.m. were collected respectively $5^{1 / 2}$ hours and $9 \frac{1}{2}$ hours after the last meal and 8 hours and 4 hours before the following one), while 1 sample, at 8 p.m., represents the blood glucose level $1 \frac{1}{2}$ hours after the meal.

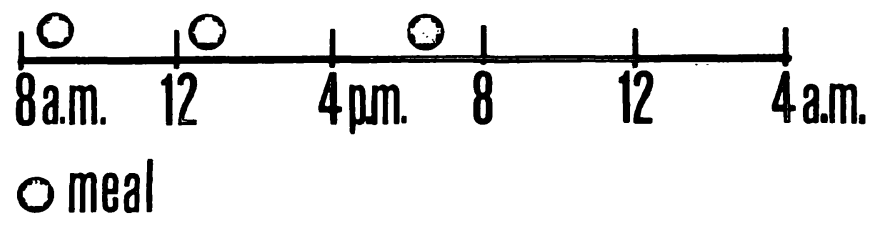

Fig. 1. Time relationship between meals and blood sampling.

Calory intake differed from patient to patient. According to our criteria $[5,6,7,8,9,10]$ each patient had been invited to choose her first menu without any restriction on quality or quantity. Retrospective analysis showed that the calory content averaged $1900 \mathrm{cal} / 24$ hours and composition, protein glucose and lipids, were respectively $15.5 \%, 53.2 \%, 31.3 \%$, with fluctuations of $\pm 10 \%$ in most cases [8].

The M.T.D. of insulin was administered to patients with both clinical and latent diabetes, as established in every case by means of a simple method $[4,5$, $6,7,8,10]$.

Blood glucose was measured in an autoanalyzer in the hospital laboratory using the oxidase method.

Between 1971, when the 24-hour glycemia check became a routine test, and 1975,388 pregnant diabetics ( $96.5 \%$ of cases treated in the same period), 251 with latent and 137 with clinical diabetes, were checked. The number of tests differed from patient to patient, because they were performed weekly and because the duration of the first period of hospitalization (needed to establish the M.T.D. of insulin) and the number and the length of subsequent hospitalization periods (needed to maintain the M.T.D. of insulin in the course of pregnancy) differed.

The current report presents data concerning two glycemia checks made during the first hospitalization. The first was performed before starting our treatment (patients with latent or chemical diabetes who had not yet been treated with insulin, and patients with clinical diabetes that was being conventionally compensated), the second after having established the M.T.D. of insulin, i.e., before the patients were discharged from hospital. For various reasons one or other of these two tests were not performed in a few cases, while the set of samples was incomplete in other cases.

161 patients ( $41 \%$ of the cases tested) with the complete set of samples in both tests were included in the study.

The patients were divided into groups. The first comprised cases with potential diabetes (positive family and/or personal history) and positive oral glucose tolerance test (O.G.T.T.) (WhITE's class A). O.G.T.T. was performed and evaluated as

Tab. I. Fasting blood sugar (mg\%) mean and $95 \%$ confidence interval for the mean.

before treatment

at the M.T.D.

\begin{tabular}{|c|c|c|c|c|c|c|c|c|c|c|c|}
\hline \multicolumn{2}{|c|}{$\begin{array}{l}\text { WHITE's } \\
\text { classes } \\
\text { ( } n^{\circ} \text { of cases) }\end{array}$} & $\overline{\mathbf{x}}$ & $\bar{x} \pm t 0.95 \mathrm{se}$ & $\mathrm{p}$ & \multicolumn{2}{|c|}{$\begin{array}{l}\text { Control } \\
\text { group } \\
\text { (69 cases) }\end{array}$} & $\mathbf{p}$ & \multicolumn{2}{|c|}{$\begin{array}{l}\text { WHITE's } \\
\text { classes } \\
\text { ( } \mathrm{n}^{\circ} \text { of cases) }\end{array}$} & \multirow{2}{*}{$\begin{array}{c}\bar{x} \\
76.3\end{array}$} & \multirow{2}{*}{$\begin{array}{l}\overline{\mathrm{x}} \pm \mathrm{t} 0.95^{\mathrm{se}} \\
78.5 \\
74.2\end{array}$} \\
\hline $\mathbf{A}$ & (95) & 85.5 & $\begin{array}{l}88.3 \\
82.8\end{array}$ & $\leqslant 0.001$ & \multirow{4}{*}{69.3} & \multirow{3}{*}{$\begin{array}{l}71.4 \\
67.2\end{array}$} & $\leqslant 0.01$ & $\mathbf{A}$ & (95) & & \\
\hline B-F & $(66)$ & 132.9 & $\begin{array}{l}148.0 \\
119.3\end{array}$ & $\leqslant 0.001$ & & & $>0.05$ & B-F & (66) & 71.1 & $\begin{array}{l}77.3 \\
65.4\end{array}$ \\
\hline B-C & (36) & 123.9 & $\begin{array}{l}142.6 \\
107.7\end{array}$ & $\leqslant 0.001$ & & & $>0.05$ & B-C & $(36)$ & 74.4 & $\begin{array}{l}81.5 \\
67.9\end{array}$ \\
\hline \multicolumn{2}{|c|}{ D-E-F (30) } & 144.4 & $\begin{array}{l}170.2 \\
122.5\end{array}$ & $\leqslant 0.001$ & & & $>0.05$ & \multicolumn{2}{|c|}{ D-E-F (30) } & 67.3 & $\begin{array}{l}78.0 \\
58.1\end{array}$ \\
\hline
\end{tabular}

$\overline{\mathbf{x}}=$ mean

$\bar{x} \pm$ t $0.95^{\text {se }}=95 \%$ confidence interval for the mean 
described by O'Sullivan [2]. The second group comprised cases with clinical diabetes (WHITE's classes B, C, D, E, F). Patients with chemical diabetes and a fasting blood glucose level of $\geqslant 130 \mathrm{mg} \%$ were added to those classified in class B. The patients with clinical diabetes were also divided into two groups, i.e., cases without vascular complications (WHITE's classes B and C) and those with these complications (WHITE's classes D, E and F). The mean values of blood glucose at fasting and over the 24-hour period (i.e., the mean value of the complete set of 6 samples) in these groups were compared with those of a control group. The control group consisted of 69 pregnant women admitted to hospital for various reasons. 20 of them were in the first half, and 49 in the second half of their pregnancies. Their history was negative for diabetes. They were not on a diet. Times of blood sampling and meals were the same as in the pregnant diabetic group.

The distribution of values was asymmetrical in both the diabetics and control groups (but more so in the diabetic group). A statistical analysis was therefore performed after converting numerical figures into their logarithms, thereby enabling distribution to be normalized. The final conversion of logarithms into numerical figures explains why the upper fiducial limits (see Tabs. and Figs.) have higher values than the lower. The statistical differences between the mean values of the diabetic groups and control group were verified with the z-test [3], as is recommended in the case of populations with different variances.

\section{Results}

Before applying our treatment, the average blood glucose values at fasting (Tab. I, Fig. 2) and over the 24-hour period (Tab. II, Fig. 3) in each group of pregnant diabetics were higher than the corresponding mean values in the control group. Differences vis-à-vis the control group increased, from patients with latent diabetes to those with clinical diabetes and, among the latter, from those with no vascular complications to those with these complications. All differences were statistically significant $(p \leqslant 0.001)$.

At the M.T.D. of insulin, both fasting (Tab. I, Fig. 2) and 24-hour (Tab. II, Fig. 3) blood glucose mean values of pregnant diabetics were very close to the corresponding values in the control group. There is no statistical difference except in class $A$. The mean value of each diabetic group was almost the same. As patients with clinical diabetes had higher blood glucose values than those with latent diabetes, treatment brought a more drastic reduction in the former group than in the latter.

Before treatment, both at fasting and over the 24 hour period, the individual blood glucose values of patients with clinical diabetes were distributed over a wide range. At the M.T.D. of insulin, individual blood glucose values are closely distributed around their mean values (Figs. 4, 5).

Tab. II. 24 hours blood sugar (mg\%) mean and $95 \%$ confidence interval for the mean.

before treatment at the M.T.D.

\begin{tabular}{|c|c|c|c|c|c|c|c|c|c|c|c|}
\hline \multicolumn{2}{|c|}{$\begin{array}{l}\text { WHITE's } \\
\text { classes } \\
\text { ( } n^{\circ} \text { of cases) }\end{array}$} & $\overline{\mathbf{x}}$ & $\bar{x} \pm t 0.95^{s e}$ & $\mathrm{p}$ & \multicolumn{2}{|c|}{$\begin{array}{l}\text { Control } \\
\text { group } \\
\text { (69 cases) }\end{array}$} & p & \multicolumn{2}{|c|}{$\begin{array}{l}\text { WHITE's } \\
\text { classes } \\
\text { ( } n^{\circ} \text { of cases) }\end{array}$} & $\overline{\mathbf{x}}$ & $\bar{x} \pm 0.95^{s e}$ \\
\hline A & (95) & 87.7 & $\begin{array}{l}89.9 \\
85.5\end{array}$ & $\leqslant 0.001$ & \multirow{4}{*}{79.1} & \multirow{3}{*}{$\begin{array}{l}81.0 \\
77.3\end{array}$} & $\leqslant 0.001$ & $\mathbf{A}$ & (95) & 70.5 & $\begin{array}{l}72.5 \\
68.5\end{array}$ \\
\hline B-F & $(66)$ & 144.7 & $\begin{array}{l}157.4 \\
133.1\end{array}$ & $\leqslant 0.001$ & & & $>0.05$ & B-F & $(66)$ & 75.4 & $\begin{array}{c}78.8 \\
72.2\end{array}$ \\
\hline B-C & (36) & 137.3 & $\begin{array}{l}152.1 \\
123.9\end{array}$ & $\leqslant 0.001$ & & & $>0.05$ & B-C & $(36)$ & 75.5 & $\begin{array}{l}80.1 \\
71.2\end{array}$ \\
\hline \multicolumn{2}{|c|}{ D-E-F (30) } & 154.2 & $\begin{array}{l}176.7 \\
134.6\end{array}$ & $\leqslant 0.001$ & & & $>0.05$ & \multicolumn{2}{|c|}{ D-E-F (30) } & 75.4 & $\begin{array}{c}80.7 \\
70.5\end{array}$ \\
\hline
\end{tabular}

$\overline{\mathbf{x}}=$ mean

$\bar{x} \pm t 0.95^{\text {se }}=95 \%$ confidence interval for the mean.

J. Perinat. Med. 8 (1980) 
FASTIHG BLOOD SUGAR

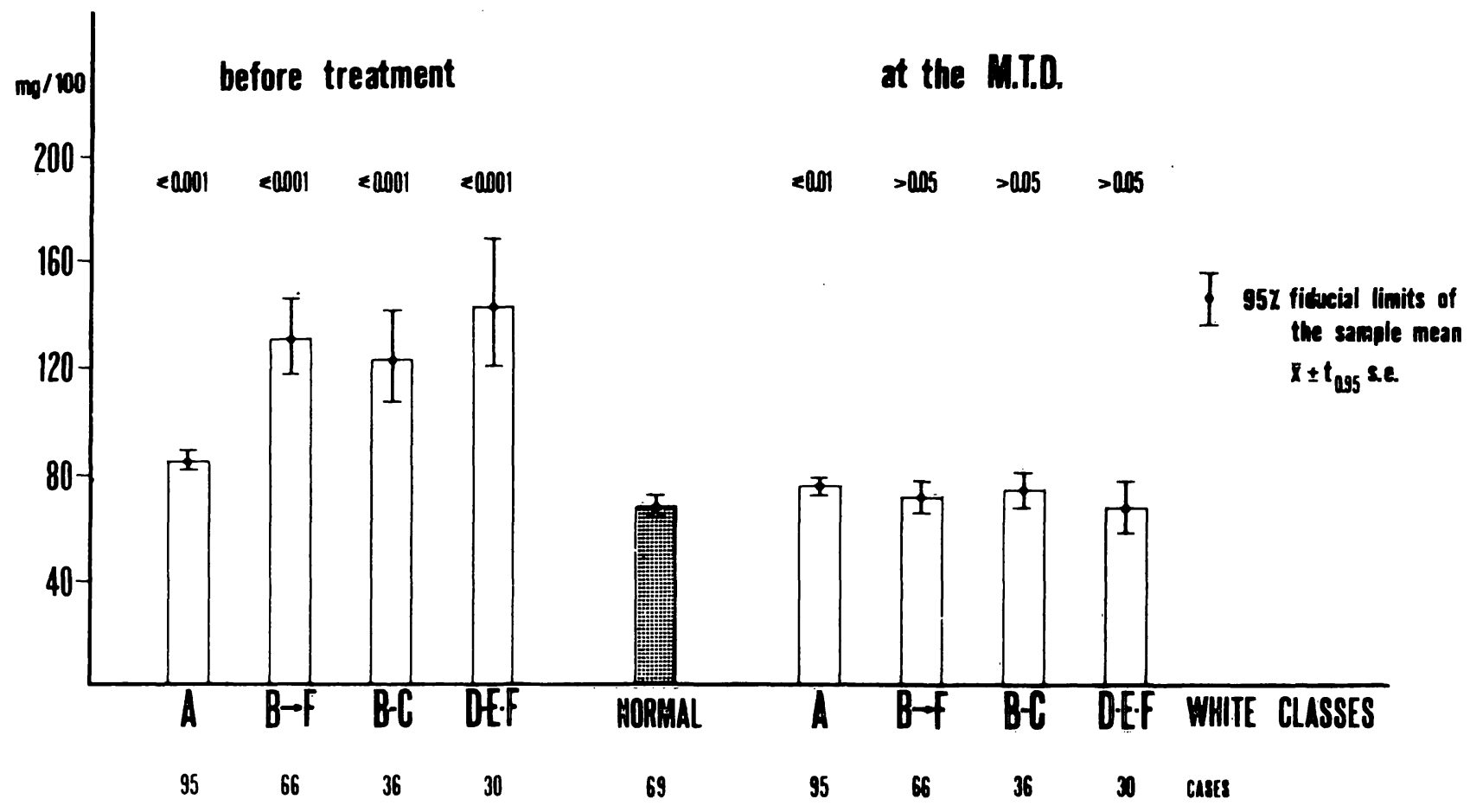

Fig. 2. Fasting blood sugar ( $\mathrm{mg} \%)$ mean and $95 \%$ confidence interval for the mean.

24 HOURS BLOOD SUGAR
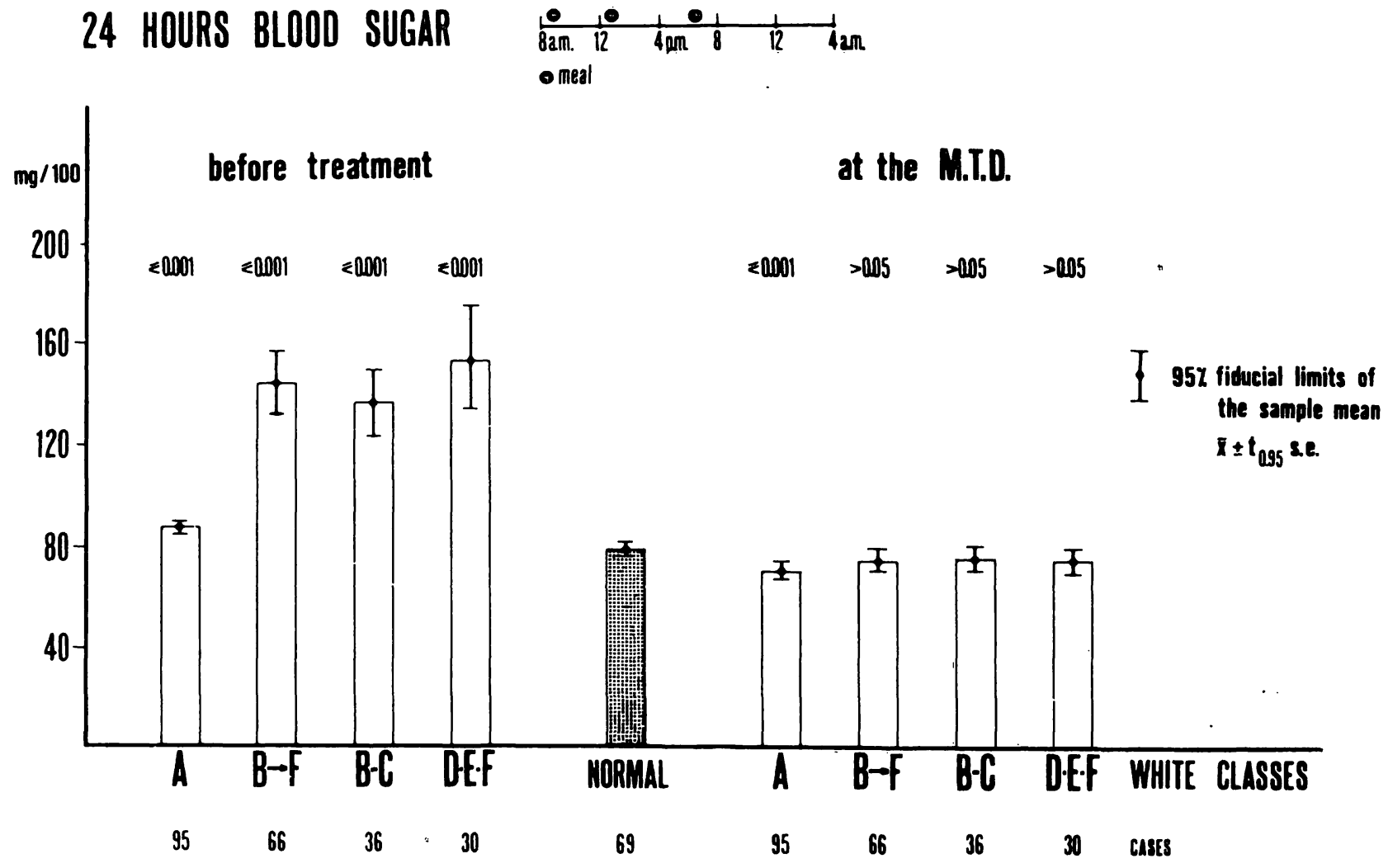

Fig. 3. 24 hours blood sugar $(\mathrm{mg} \%)$ mean and $95 \%$ confidence interval for the mean. 
FASTHGG BLOOD SUGAR

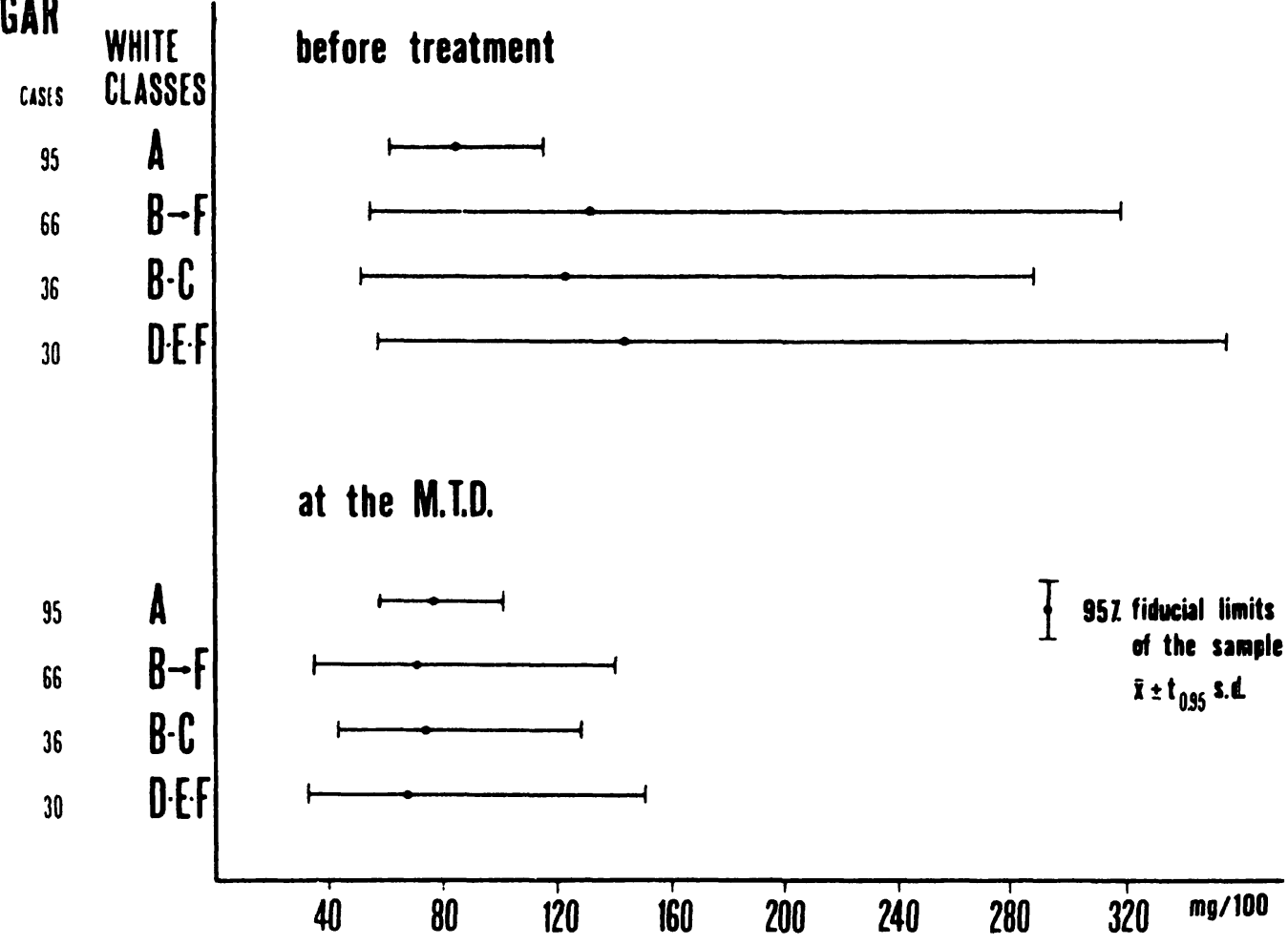

Fig. 4. Fasting blood sugar ( $\mathrm{mg} \%$ ) mean and $95 \%$ confidence interval for the sample.

24 HOURS BLOOD SUGAR

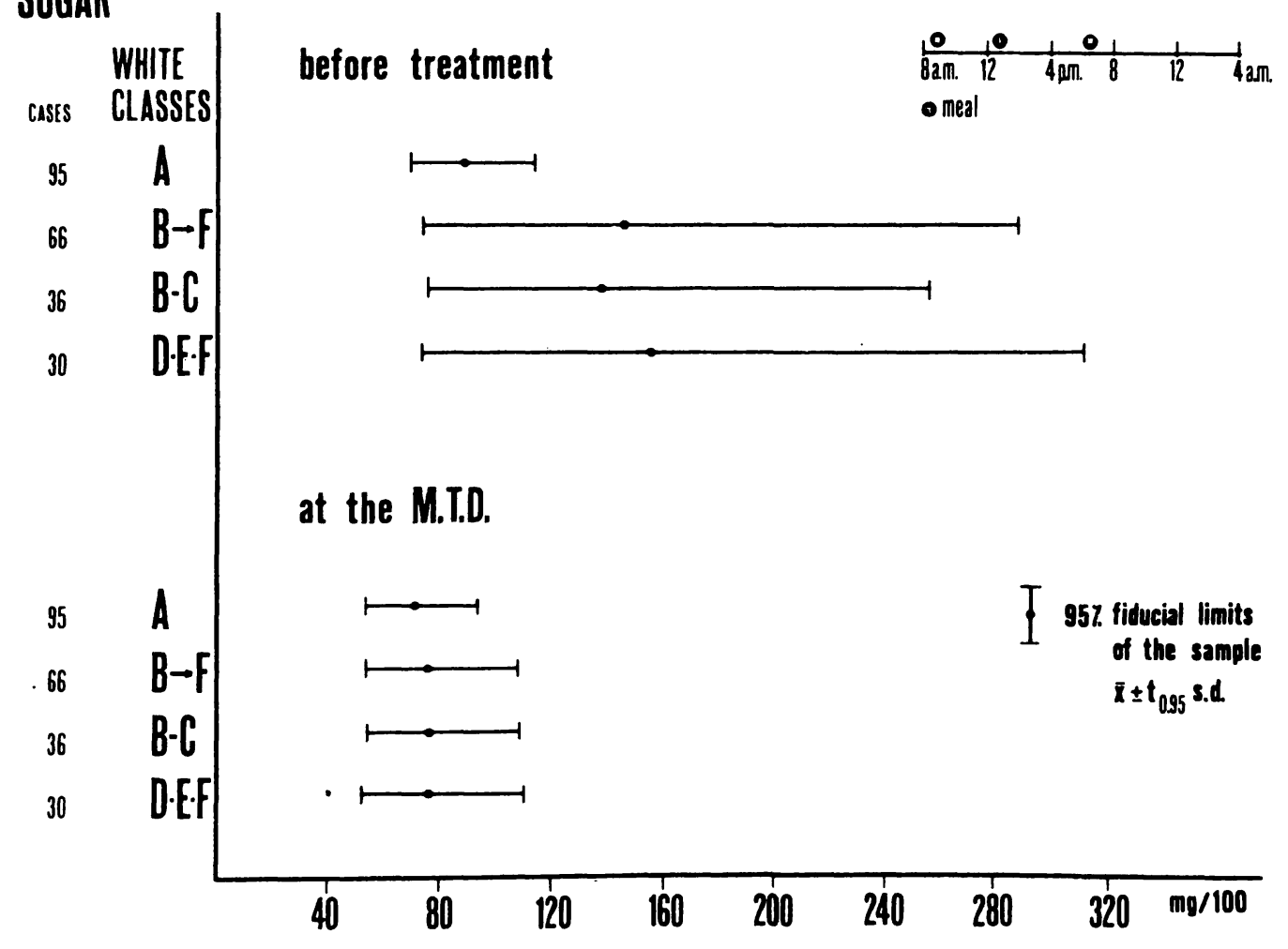

Fig. 5. 24 hours blood sugar (mg\%) mean and 95\% confidence interval for the sample. 


\section{Discussion}

It is generally agreed that the better the control of diabetes in pregnant diabetics the better the chance of a favourable outcome of pregnancy. Numerous investigations have therefore been carried out to answer the question: what is optimum control of diabetes in pregnancy? It seemed reasonable to look for the answer to this question by attempting to answer another, namely what is the optimum blood glucose value? On this point no agreement has yet been reached. The blood glucose value which pregnant diabetics require to maintain metabolic compensation differs from author to author. In any case, the choice of a predetermined blood glucose value as the aim of insulin treatment is more a practical than an ideal solution.

Blood glucose represents the index of only one metabolic compartment among those influenced by insulin. The normal value of blood glucose is an individual and not a general characteristic, which can vary considerably and change from day to day, depending on many factors such as physical activity, diet. etc. Moreover, the fear of hypoglycemic coma leads one to select a predetermined blood glucose value which is risk-free but far from what is generally considered a normal blood glucose value. On the contrary, minor disturbances in maternal metabolism, as occur with latent diabetes, are of great consequence to the development of the foetus. Pregnant diabetics in the same metabolic and clinical conditions show varying blood glucose reductions brought about by the same quantity of insulin and viceversa. In other words, the reduction in hyperglycemia is not to some extent a dose-related phenomenon. Hence the relative frequence of hypoglycemic coma in case studies of pregnant diabetics while at the same time it is difficult, and often impossible, in practice to achieve predetermined blood glucose values. In the literature these cases have been retrospectively defined as "non-compensated".
This disadventages of using blood glucose as a guideline in the treatment of pregnant diabetics are overcome by our method of insulin administration. In fact, M.T.D. of insulin is not established on the basis of maternal blood glucose but on the basis of clinical signs $[4,5,6,7,8,10]$. M.T.D. is easily established in a short time in all cases and therefore is guaranteed "a priori" (in our case study no cases were judged "a posteriori" as poorly compensated, i.e., cases in which M.T.D. was not reached). Hypoglycemic coma is largely prevented by the particular method of insulin administration, which entails a step-by-step increase in insulin dosage (only 6 cases of coma occurred in 479 pregnant diabetics). The results of this study show that blood glucose progressively falls as insulin increases and levels out at the M.T.D. to unforeseeable and non-predetermined values, which differ from case to case, as in a normal population, and whose mean values correspond to the mean values of a normal population. Normalization of blood glucose is ensured irrespective of the degree of diabetes and that of hyperglycemia. In our case study, different WHITE's classes with differing degrees of hyperglycemia before starting treatment reached almost overlapping blood glucose values at the M.T.D. of insulin. The range of individual values was also clearly narrowed.

These positive results complement the positive clinical results of our case study $[1,5,6,7,8,10]$ which were summarized at the beginning of this paper. Since our pregnant diabetics underwent their maximal tolerated dose of insulin, it is not easy to foresee any, further improvement in the outcome of pregnancy through a further improvement in insulin treatment. At the same time, each day's results confirm our confidence in the method we have used to treat pregnant diabetics since 1963.

\section{Summary}

Between 1970 and 1975 a 24-hour blood glucose check on hospitalized pregnant diabetics (including controls at fasting and five samples of capillary blood at 4-hour inter- vals) was routinely performed on a given day of every week. Time intervals of blood collections after meals were 4 hours or more in five samples and $1 \frac{1}{2}$ hours in one sample (8 p.m.). 
Insulin was administered to the maximum tolerated dose (M.T.D.) both to pregnant women with latent and to those with clinical diabetes $[4,5,6,7,8,10]$. The blood glucose data of cases coverning the complete set of samples both before starting treatment (no insulin therapy given to patients with latent or chemical diabetes and therapy according to traditional criteria given to patients with clinical diabetes) and after reaching the M.T.D. of insulin (161 cases) were compared with data from 24-hour blood glucose checks on 69 non-diabetic pregnant women (control group).

Before starting the treatment the average blood glucose values at fasting and over the 24-hour period were higher in each group of pregnant diabetics (latent diabetes: 95 cases; clinical diabetes: 66 cases; without vascular complications: 36 cases; with vascular complications: 30 cases) than in the control group.

Differences vis-à-vis the control group were greater in

Keywords: Blood sugar, insulin, pregnancy and diabetes. patients with clinical than in those with latent diabetes, and in patients with vascular complications than in those without. All differences were statistically significant (Tabs. I, II; Figs. 2, 3). Individual blood glucose values in patients with clinical diabetes were widely distributed around their mean values (Figs. 4, 5). At the M.T.D. of insulin, the mean values of diabetics and control groups were almost the same. There was no statistical difference between pregnant diabetics (except in patients with latent diabetes) and the control group (Tabs. I, II; Figs. 2, 3). Individual blood glucose values were distributed in a narrow range (Figs. 4, 5).

The normalization of blood glucose was not the original purpose of our treatment, but the treatment did result in normalization. This positive result is in agreement with the positive perinatal outcome of the cases studied $[1,5$, $6,7,8,10]$. These results confirm our confidence in the particular method of insulin therapy that we use.

\section{Zusammenfassung}

Einstellung der Blutzuckerwerte bei schwangeren Diabetikern mit der maximal tolerierten Insulindosis

Zwischen 1970 und 1975 wurde bei hospitalisierten schwangeren Diabetikerinnen routinemäßig einmal pro Woche ein Blutglucoseprofil über 24 Stunden erstellt. Wir führten Nüchternblutbestimmungen sowie 5 Glucosebestimmungen im Abstand von ca. 4 Stunden nach den Mahlzeiten und 1 Glucosebestimmung 1,5 Stunden nach der Mahlzeit (20 Uhr) durch.

Sowohl den Schwangeren mit latentem Diabetes wie denen mit klinisch manifestem Diabetes wurde Insulin bis zur maximal tolerierten Dosis verabreicht $[4,5,6,7,8$, 10]. Die Blutglucoseprofile, die vor Beginn der Therapie bzw. nach Erreichen der maximal tolerierten Dosis in der oben beschriebenen Weise erstellt worden waren, wurden mit Profilen aus einer Kontrollgruppe nicht-diabetischer Schwangerer verglichen. Voraussetzung war, daß die Schwangeren mit latentem Diabetes vorher nicht mit Insulin therapiert wurden und der manifeste Diabetes nach klassischen Kriterien eingestellt war. Insgesamt untersuchten wir 161 pathologische Fälle, die folgenden Untergruppen zugeordnet wurden: 95 Patientinnen mit latentem Diabetes; 66 Patientinnen mit manifestem Diabetes, davon 36 ohne und 30 mit vaskulären Komplikationen. Die Kontrollgruppe umfaßte 69 nicht-diabetische Schwangere.

Vor der Behandlung waren die mittleren Glucosewerte im Nüchternblut wie auch über den Tag verteilt in allen Gruppen erhöht gegenüber der Kontrollgruppe. Die Abweichungen vom Normalwert waren beim manifesten Diabetes größer als beim latenten. Ebenso war die Differenz gegenüber der Kontrollgruppe bei Patientinnen mit Gefäßkomplikationen höher als bei Patientinnen ohne vaskuläre Komplikationen. Alle Unterschiede waren statistisch signifikant (Tab. I, II, Abh. 2, 3). Die Einzelwerte von Patientinnen mit manifestem Diabetes wiesen eine große Streuung um ihre Mittelwerte auf (Abb. 4, 5).

Unter der Therapie mit der maximal tolerierten Insulindosis waren Mittelwerte von Diabetikern und Kontrollpersonen fast gleich. Außer in der Gruppe der latenten Diabetiker gab es keine statistisch signifikanten Unterschiede gegenüber dem Normalkollektiv (Tab. I, II, Abb. 2, 3). Jetzt fand sich auch eine weitaus geringere Streuung der Einzelwerte um ihre Mittelwerte (Abb. 4, 5).

Die Einstellung der Blutglucose auf Normalwerte war nicht das eigentliche Ziel unserer Behandlung. Sie resultierte jedoch aus unserer Therapie und wirkte sich günstig auf das perinatale Geschehen aus, wie die von uns unter diesem Aspekt weiterhin untersuchten Fälle beweisen $[1,5,6,7,8,10]$. Wir fassen unsere Ergebnisse als Bestätigung für die von uns eingesetzte Insulintherapie auf.

Schlüsselwörter: Blutzucker, Diabetes in der Schwangerschaft, Insulin.

\section{Résumé}

Normalisation de la gly cémie chez la diabétique gravide au moyen de la dose maximale d'insuline tolérée (M.T.D.). Des Bilans des glycémies de 24 heures, comprenant la glycémie à jeun ainsi que cinq valeurs capillaires à des intervalles de 4 heures, ont été réalisés un jour donné de chaque semaine en tant qu'examen de routine chez l'ensemble de nos diabétiques gravides hospitalisées entre 1970 et 1975 . L'intervalle de temps entre les repas et les prises de sang était de 4 heures, sauf pour la valeur de 8 heures qui était obtenue 1 heure et demie après le repas. 
L'insuline a été administrée selon la dose maximale tolerée (M.T.D.) aussi bien aux patientes au diabète latent qu'à celles au diabète patent $[4,5,6,7,8,10]$. Les gly cémies des cas où l'ensemble des échantillons a été obtenu dans les deux groupes - celui avant traitement (comprenant les patientes sans traitement insulinique pour diabète latent ou chimique, ainsi que celles traitées de façon conventionnelle par l'insuline pour diabète patent) et après obtention de la M.T.D. d'insuline (161 cas), ont été comparées avec les valeurs de profils de 24 heures de glycémie chez 69 femmes enceintes et non diabétiques (groupe témoin).

Avant le début du traitement les glycémies moyennes à jeun ainsi que celles de l'ensemble de la période de 24 heures étaient supérieures dans chaque groupe de diabétiques gravides en comparaison avec celles du groupe témoin (diabète latent: 95 cas; diabète patent: 66 cas dont 36 sans complications vasculaires et 30 avec de telles complications).

Les différences vis-à-vis du groupe témoin étaient plus marquées chez les patientes au diabète patent par rapport à celles au diabète latent ainsi que chez les patientes avec des complications vascularies que chez celles sans telles. Toutes ces différences étaien't statistiquement significatives.

Les glycémies individuelles des patientes au diabète patent se distribuaient largement autour de leurs valeurs moyennes (Figures 4, 5). A la M.T.D. d'insuline les valeurs moyennes des diabetiques et du groupe témoin étaient semblablement les mêmes. L'on ne notait pas de différence significative entre les diabétiques gravides (les patientes au diabète latent mises à part) et le groupe témoin (Tableaux I et II; Figures 2 et 3 ). Les glycémies individuelles se distribuaient dans des limites étroites (figures 4, 5).

La normalisation des glycémies n'était pas le propos initial de notre traitement, mais cecui-ci résultait de la normalisation. Ce résultat positif se trouve en accord avec l'évolution périnatale positive des cas étudiés $[1,5$, $6,7,8,10]$. Ces résultats nous confirment dans notre confiance en la méthode particulière de thérapeutique insulinique que nous avons utilisée.

Mots-clés: Diabète et grossesse, gly cémie, in suline.

Acknowledgement: The statistical analysis was performed by PARPINELLI TRE s.r.l., Milan (Italy).

\section{Bibliography}

[1] Barbarani, V., P. Peneff, F. CAtTAneo, S. VITALI, A. MARINI: Les nouveau-nés de mère diabétique dont le diabète fut strictement contrôlé durant la grossesse (Résultats cliniques dans 476 cas). Rev. Méd. Suisse rom. 98 (1978) 259

[2] O'SUllivaN, J. B., C. M. MAHAN: Criteria for the oral glucose tolerance test in pregnancy. Diabetes 13 (1964) 278

[3] OSTLE, B.: Statistics in research. Second Edition. The Iowa State University Press. p. 95

[4] ROVERSI, A. S.: Du traitment insulinique du diabète et de ses complications. La thérapie insulinique prehypogly cémisante (T.I.P.I.) Press Méd. 12 (1957) 243

[5] ROVERSI, G. D., V. CANUSSIO: Neue Aspekte der Diabetes-Therapie in der Gravidität. In: SALING, E., F.J.SCHULTE: Perinatale Medizin. 3.Deutscher Kongreß für Perinatale Medizin. Berlin, 1970. Thieme, Stuttgart 1972

[6] ROVERSI, G. D., V. CANUSSIO, M. GARGIULO, G. B. CANDIANI: The intensive care of perinatal risk in pregnant diabetics (136 cases): A new therapeutic scheme for the best control of maternal disease. J. Perinat. Med. 1 (1973) 114
[7] ROVERSI, G. D., V. CANUSSIO, M. GARgiUlo: Insulin in gestational diabetes. In: CAMERINIDAVAlOS, R. S., H. S. COLE: Early Diabetes in Early Life. Academic Press, New York-San Francisco-London 1975

-[8] Roversi, G. D., V. CANUSSIO, M. GARgiUlo: New aspect of diabetic therapy during pregnancy. In: DUdENhausen, J. W., E. SAlING, E. SCHMIDT: Perinatale Medizin. 7. Deutscher Kongreß für Perinatale Medizin. Berlin, 1974. Thieme, Stuttgart 1975

[9] ROVERSI, G. D., M. GARGIULO, U. NICOLINI, E. FERRAZZI, E. PEDRETTI, L. GRUFT, G. TRONEONI: Maximal tolerated insulin therapy in gestational diabetes. Diabetes Care (in press)

[10] Roversi, G. D., M. GARGIULO, U. NICOLINI, E. PEDRETTI, A. MARINI, V. BARBARANI, P. PENEFF: A new approach to the treatment of diabetic pregnant women: 479 cases (1963-1975). Amer. J. Obstet. Gynec. 135 (1979) 567

Received November 15, 1979: Revised February 19, 1980. Accepted March 28, 1980.
Prof. Dr. G. D. Roversi Via E. Besana, 6 I-20122 Milano / Italy 